\title{
Reframing Indigenous Territories: Private Property, Human Rights and Overlapping Claims
}

\author{
Brian Thom
}

$\mathrm{T}$ he legal, social, political, and economic relationships concerning the title to and governance of indigenous territories continue to have an uneasy, at times conflict-laden quality, in spite of decades of land claims talks, legal precedents, and the recognition of indigenous rights by the United Nations. At the heart of this situation rests a profound difference in vision between indigenous territorial relations ${ }^{1}$ and state forms of property. ${ }^{2}$ The consequences of these differing abstractions of territory and property relations are significant and bear on basic human rights of indigenous peoples.

This article offers an ethnography of local indigenous peoples' work to engage property discourses of the state and make sense of their own territoriality in their land and governance negotiations with the state. My work provides a foundation for analyzing the social and political consequences of how indigenous territoriality is abstracted and articulated within these discourses of state property relations, and for considering the implications of charting territorial relations in ways that better consider indigenous perspectives. Based on extensive fieldwork done with Coast Salish peoples on Vancouver Island, British Columbia, Canada, and with members of these indigenous communities as they traveled to Washington, DC, in 2008, 2009, and 2011to press their property claims as human rights, my analysis focuses on the shifting set of BRIAN THOM is an assistant professor in the department of anthropology at the University of Victoria. He has had extensive experience with the British Columbia Treaty Process, with research focused on the political, social, and cultural processes that have surrounded Coast Salish peoples' efforts to resolve Aboriginal title and rights claims and establish self-government. 
property discourses mobilized by the state and indigenous players in land and governance negotiations. I reveal how the state categories of "private property" and "overlapping claims" destabilize and marginalize indigenous peoples' efforts in seeking recognition of their property and cultural rights and in reconciling colonial land settlement, particularly when these efforts are inconvenient to private and corporate interests that have developed since the days of historic "land grabs."

Indigenous peoples have also asserted their own categories of "territory" and "property" within these debates. At the same time as they mobilize these concepts in ways that make their own territorial relations familiar to state actors, they also work to retain their local character and to enfold the fabric of social, economic, and political orders in ways that make sense in indigenous terms. As indigenous people continue to reconfigure their governance and regain control of culturally significant places and resources, sorting out the future of territorial relations in ways that respect and incorporate indigenous aspirations, sociality, and visions of a good life distinctly connected to place has become a central problem. ${ }^{4}$ All too often the state's expectations that indigenous communities should delineate exclusive territories have exacerbated preexisting tensions in overlapping territorial relationships, or created new ones. ${ }^{5}$ In his work with Inuit land claims thirty years ago, geographer William Wonders revealed that while the imperatives to define boundaries seem evident to state actors, indigenous communities do not always fully realize the implications of these imperatives until the shift from strategies of sharing to strategies of exclusion creates problems on the ground. ${ }^{6}$

Some strained relationships among indigenous communities produced by these overlapping territorial cartographies have erupted in legal disputes, such as the recent court cases in Apsassin, Cook, Cowichan Tribes, Gitanyow, Luuxhon, Semiabmoo, Sencoten, and Tseshabt. ${ }^{7}$ Frequently these legal contests take place in a context in which the state allocates resources or benefits in terms that do not make sense to local expectations of sharing, reciprocity, and respect, or when all neighboring communities do not agree upon significant decisions affecting land, such as industrial development, resource alienation, or extinguishment of title interests. In other instances, the state has argued that the unresolved territorial claims of First Nations actually prevent them from offering reconciliation or sharing in revenues or decision-making in territories claimed. ${ }^{8}$ Such disputes are not unique to Canada, as can be seen in the burgeoning literature on parallel issues in Australia and New Zealand. ${ }^{9}$ In many of these legal contests, teachings rooted in the wisdom of indigenous territoriality are subsumed by legal doctrine and bureaucratic practice. ${ }^{10}$ From these indigenous experiences, it becomes clear how characterizing territory as 
necessarily being "exclusive" to be legitimate actually has the potential to disenfranchise indigenous peoples of their lands.

Indigenous legal scholar Johnny Mack has theorized the consequences of engaging these state discourses: "we [as indigenous peoples] are lured into a liberal field by an offering to recognize our claims, but the recognition turns out to be a domestication in which the claims are transformed to fit with the current structure of the liberal state."11 Mack attends these observations with a powerful discussion of how several Nuu-chah-nulth communities embraced the apparent recognition of indigenous land title and laws, only to find that when this recognition is codified into treaty settlement lands and governance, indigenous relationships to land are fundamentally transformed by internalizing colonial attitudes and processes. Elizabeth Povinelli, working in Australia, shows how state categories and logics have significant power to perpetuate liberal ideas and curtail the possibility of truly incorporating indigenous ontologies into state-ordered discourses. ${ }^{12} \mathrm{Her}$ analysis points to a seeming irreconcilability of indigenous and state truths about knowledge of and ways of relating to land and the beings that dwell within it.

These scholars' conclusions raise compelling and difficult problems. How may indigenous peoples continue to exercise their cultural and property rights on private land? Is it possible for the state to provide resolution and reconciliation for indigenous peoples whose claims intricately overlap? Where these seemingly intractable problems exist, are restitution, reconciliation, or even the recognition of basic human rights possible in the twenty-first century? Must indigenous communities simply accept state framing of property and territory, or are there opportunities for indigenous peoples' relationships to land-indigenous territoriality-to persist and coexist?

My ethnographic work in Coast Salish communities highlights these challenges and offers insights and strategies for addressing such concerns. While Coast Salish peoples continually fine-tune the language of their territorial arguments - which range from negotiating land claims to pressing the international community to recognize the human rights consequences of territorial alienation-they work to stay consistent with the cultural principles that underlie their land tenure system and their overall social relationships within their territories. Although framing "territory" in these contexts entails a significant challenge of cultural translation that is fraught with limitations, indigenous peoples' active and conscious work in producing this discourse opens up possibilities for indigenous territorial lifeways to endure.

Scholars and indigenous activists are increasingly recognizing that, in a cultural landscape being transformed by neoliberal exploitation, these possibilities are an important part of indigenous life projects that are inspired by maintaining relationships of respect and reciprocity between humans and 
other forms of life. In working to place relationships and priorities for living well at the center, these life projects are characterized not only by conflict, but also negotiation and accommodation. ${ }^{13}$

\section{From Hope to Stalemate: BC Treaty Negotiations}

For six Coast Salish communities from Vancouver Island, land and governance negotiations have all but failed. This negotiation failure has occurred in spite of more than sixteen years of talks and more than $\$ 25$ million of negotiation loan debt incurred by the six-member First Nations of the Hul'qumi'num Treaty Group (hereafter HTG). HTG consists of Cowichan Tribes, Chemainus First Nation, Penelakut Tribe, Lyackson First Nation, Halalt First Nation, and Lake Cowichan First Nation. As a negotiator, adviser, and researcher, I worked full-time for HTG between 2000 and 2010, and since then I have had an ongoing advisory role. Like so many other First Nations in British Columbia, Hul'qumi'num people have been involved in these modern-day treaty negotiations because the legal, social, political, and constitutional relationships concerning the title to and governance of their territories has never been formalized with the state. No treaty or any other formal arrangement establishes a reconciliation of Hul'qumi'num peoples' prior occupation of their lands with colonial settlement and the establishment of the Canadian state. While a process for modern-day treaty negotiations was established in 1993, there are only three agreements in effect among the province's 203 recognized First Nations: Nisgaa, Tsawwassen, and Maa-nulth.

The HTG-member First Nations communities joined the British Columbia Treaty Process in 1993. By 2001, the HTG had secured a mandate from their community to negotiate for territorial recognition. Negotiations from 2001 to 2007 were intense, with tripartite main table meetings among representatives from HTG and the provincial and federal governments taking place up to six days per month. Though the HTG negotiation team brought principled, well-researched options to the table, "mandate" binders handed to government negotiators constrained their ability to agree to binding treaty language that strayed far from predetermined solutions. HTG chief negotiator Robert Morales came to see these talks as something of a sham: from his viewpoint, the treaty process was not providing an avenue for meaningful two-way negotiation on substantive issues where indigenous visions of their future could be implemented within the text of the treaty.

Drawing on an impressive province-wide network of Aboriginal negotiators and chiefs, Morales began lobbying to establish a process where principled negotiations on the substantive issues could occur. Bringing together negotiators from 
more than sixty First Nations across the province who had reached a similar impasse, the HTG leadership helped establish the "Unity Protocol," which provided a framework for collective negotiations at a "Common Table" with Canada and British Columbia on a narrow range of deal-breaker issues. Though several minor adjustments to the provincial and federal mandates were made, many First Nations negotiators concluded that regressive government positions on self-government, co-management, fisheries, fiscal relations, and the constitutional status of lands, thwart any prospect for reaching treaty settlement. ${ }^{14}$

While the HTG leadership shared these Common Table concerns, the most pressing local issue for the HTG remains the unwillingness of the state to reconcile the near-complete privatization of indigenous territories on Vancouver Island by the 1884 E\&N Railway Grant. ${ }^{15}$ In granting more than 800,000 hectares of land, timber, and subsurface rights to coal baron James Dunsmuir, nearly the entire traditional land base of First Nations HTG members came to be owned and occupied by coal and forest companies, private farmers, and townspeople. Today, three large forest companies own nearly the entire upper watersheds of the Nanaimo, Chemainus, Cowichan, and Koksilah rivers, while the now-settled valleys, waterfront, and islands comprise some of the highest-value Canadian real estate outside of major urban centers.

As a result of these lands being privately held, and their close proximity to the major urban centers of Victoria and Vancouver, much of the important waterfront and valley-bottom lands have been intensely developed. The forested land in the area's major watersheds are densely networked with logging roads, which are gated where they cross the holdings of three large private timber companies. Unlike forestry management on Crown lands, the provincial government has not extensively legislated forestry or environmental management on private lands. As a result much of the forested lands have been harvested three times since the 1880s and these areas are extensively clearcut. A few Island First Nations, in contrast, have relatively minor logging ventures on Indian Reserves or through small area tenures on remnant Crown lands provided by the province.

Most practical governance jurisdiction within the HTG's asserted territory now rests with a patchwork of eight different local governments, whose permissive land-use zoning has facilitated intense urban expansion in the area, particularly in the past fifteen years. Despite HTG efforts to participate in land-use planning and share in local tax revenue, local government relations have been limited to technical dialogues around shared public works service agreements, not substantive collaborative land use planning or resource sharing. In particular, battles to control the groundwater needed to feed this urban expansion have exploded in the courts, with island First Nations having limited success in getting their Aboriginal title and jurisdictional interests regarding groundwater recognized. ${ }^{16}$ 
Hul'qumi'num peoples' access to the "food basket" waterfront areas of the territory-beaches and other access points to the sea-has become massively restricted by the dense network of private homes. The provincial government has created long-term property interests for private moorage, log booms, and shellfish farm tenures, which further alienate these foreshore and intertidal areas. Moreover, pulp mill discharge, urban sewage, industrial forestry, and farming effluent have choked and contaminated local marine life food sources. ${ }^{17}$

HTG's goals in these treaty negotiations have been to reestablish a territorial land base, looking to the state for some combination of land transfer or purchase and jurisdictional recognition. Additionally, where cultural rights on lands not under indigenous governance are concerned, they seek recognition of shared decision-making authority. The Crown has largely not been amenable to pursuing these solutions. ${ }^{18}$ Rather, the state's vision in British Columbia (BC) Treaty negotiations is to complete the extinguishment of indigenous title over all but a few thousand hectares, where Hul'qumi'num peoples would have municipal-style indigenous governance and limited province-like authorities to administer social services. Small commercial forestry and fishing opportunities would be provided, but narrowly defined, and nonexclusive subsistence, cultural, and consultative rights would be recognized. Though a few other First Nations in BC have accepted agreements with these features-the Tsawwassen and Maa-nulth Final Agreements came into effect in 2009 and 2011, respectively-they largely have not met the interests of most First Nations in British Columbia, including the Hul'qumi'num Treaty Group. ${ }^{19}$

Although the quantity of privately held land is a unique, if not defining, feature of this area, there has been remarkably little space for discussion of it at the treaty table. Governments have proposed that some of the anticipated funds from settlements be used to purchase small areas of land from willing sellers, but this is a matter of cherry-picking real estate, not reconstituting territorial relations. On private land, the state refuses to consider co-management, revenue sharing, shared decision-making, or recognition of Aboriginal jurisdictions. Federal and provincial governments have said "no" to HTG proposals to constitutionally protected interjurisdictional arrangements on private land as well as arrangements for the exercise of cultural rights that are not subject to landowner veto. They have refused First Nations any long-term ability to acquire land on which First Nations jurisdictions will apply without local government veto. Remarkably, they have absolutely refused consideration of compensation for the taking of these lands. Consistent with the principle voted on by the $\mathrm{BC}$ public in the 2002 referendum on treaty talks, private lands are completely off the table, leaving HTG in a seemingly impossible situation for achieving its mandate of reconstituting territorial relations. 


\section{A Call to the InTERnational COMmunity}

In a coincidence of family connections, a new approach to this stalemate presented itself. The daughter of HTG's chief negotiator decided to attend the Indigenous Peoples Law and Policy Program at the James E. Rogers College of Law at the University of Arizona, where James Anaya, Robert A. Williams Jr, and Robert Hershey have been assisting indigenous communities such as the Awas Tingi of Nicaragua, Maya communities of southern Belize, the western Shoshone, and others to articulate their land rights as human rights in various international forums. These legal scholars connected with Hul'qumi'num leadership and together formulated an appeal to the international community seeking recognition that Canada's nonnegotiable stance on private lands presents an ongoing human rights violation. By shifting the dialogue from negotiating land claims to pressing for recognition of their human rights, their hopes are to spur Canada to provide an effective remedy for the taking of their lands that is consistent with principles developing under international law, breaking the deadlock in treaty talks.

In 2007, HTG submitted a petition protesting the violation of human rights to property, culture, religious freedom, and equity under the law to one of the key human rights instruments of the Organization of American States: the Inter-American Commission of Human Rights (IACHR). Under the Organization of American States (OAS), the international body formed shortly after the end of WWII, all the nation-states of the Americas are bound to the Declaration of the Rights and Duties of Man. ${ }^{20}$ Although the OAS has no means to compel Canada to implement IACHR decisions, such international pressure regarding human rights violations may provide significant motivation for Canada to consider alternate arrangements. This approach appeals to Canada's responsiveness not only to moral outrage, but also to market pressures from the global investment community, which is averse to exposing shareholders to the risks and instability of such human rights findings.

\section{The Admissibility Hearings}

The HTG's initial petition to the IACHR took the form of a sixty-page document that set out legal arguments pertaining to admissibility on human rights grounds, as well as preliminary evidence of the customary land tenure, indigenous property rights, and cultural practices of the Hul'qumi'num peoples. ${ }^{21}$ These territorial practices, they argued, are being systematically violated by Canada's unilateral granting, permitting, and licensing of HTG First Nations' rights and interests in their traditional lands and resources to private third parties. This initial submission has been followed by numerous requests for 
clarification by the IACHR, rebuttals to Canada's responses, and, in 2008 and 2009, two admissibility hearings at the OAS headquarters in Washington, DC, that were attended by the chiefs, legal counsel, and myself. Several thousand pages of documents have been exchanged. In these documents and hearing presentations, HTG set forth how the state's private property regime has confounded and constrained the exercise of indigenous territorial practices. ${ }^{22}$

They argued that while HTG-member First Nations "continue to exercise, assert and defend their property, user, self-government and other rights and interests in their traditional lands, territories, and resources, through hunting, fishing, gathering, and spiritual and ceremonial activities unique to their culture and indigenous way of life," these practices are rarely accommodated on private lands. The close, intimate, and life-sustaining connection between Hul'qumi'num people and their traditional territory is fundamental to their cultural identity, integrity, way of life, and very survival as indigenous peoples. ${ }^{23}$ HTG illustrated these concerns with an atlas of approximately twenty-five maps illustrating the ongoing impacts of the creation of private lands. The atlas particularly highlights the clash between private-land industrial forestry, urban development, and the preferred and customary location of a broad range of subsistence and cultural practices and ancestral sites. ${ }^{24}$ HTG's atlas also provides an indigenous accounting of financial losses that shows the bare-land value of private lands within the E\&N Railway Grant to be more than $\$ 4$ billion, not including the Gulf Islands. ${ }^{25}$ Ostensibly, this figure-more than an order of magnitude larger than conventional Canadian treaty settlements - represents the kind of sum governments would need to bring to the table in order for HTG to begin reconstituting territorial relations. ${ }^{26}$

Also appended were several HTG-commissioned expert reports. Written by historians, an economist, and an archaeologist, the reports provide context for the state's specific violations, market values of the lands made private, and the ongoing failure of legislative and policy approaches. The most compelling testimony came from community members, whose affidavits told how private land impacts their exercise of cultural, place-based practices within their territories. Excerpts from the affidavit of Alex Johnny, a seventy-year-old Cowichan Tribes member, illustrates how private lands restrict his hunting practices: ${ }^{27}$

I was about thirteen when I shot my first deer on Mount Tzouhalem. Mount Tzouhalem was our hunting territory. Now-a-days you cannot go up there because of all the development - there are too many houses up there....

I would hunt deer, elk, hooters. We used to hunt all over the place-including the Gulf Islands such as Salt Spring Island, Saturna Island. However, now there 
are many developments on the islands too that prevent from hunting or gathering there....

We used to be able to go hunting and now-a-days the deer are hard to find. Sometimes you can go to the hunting territory mentioned above for three or four days and there are no animals there. My wife and I went up last week in the rain and did not see any animals. We went 150 kilometers and didn't see a thing.

Mr. Johnny's testimony highlights how developments in private land alienate people from the territories of their ancestors. People need to travel hundreds of kilometers even for basic subsistence deer and elk hunting because private land has eroded habitat and frustrates indigenous cultural practice.

This kind of testimony is substantiated by results from Canada's 1991 and 2001 Aboriginal Peoples Survey, summaries of which I included as part of the submissions. ${ }^{28}$ These census data point to how alienation from indigenous territories has sweeping consequences on the well-being of the Hul'qumi'num community. In 1991, only 9 percent of HTG peoples claimed to have regularly obtained high-protein foods from hunting and fishing; 11 percent claimed not to have obtained any food from hunting or fishing. By the turn of the twentyfirst century, survey data indicate that only about one in four Hul'qumi'num persons was engaged in traditional forms of subsistence; 12 percent claimed to have hunted, 24 percent to have fished, and 33 percent to have collected wild plants for food. Since 2001, distribution of salmon to the island Hul'qumi'num peoples has decreased from approximately fifty fish per year to five. More and more Hul'qumi'num peoples are relying on store-bought food, but grinding poverty severely restricts what they can purchase. In 2005, 57 percent of people living in Hul'qumi'num territories lived at or below the poverty line. Half of the Hul'qumi'num peoples over the age of fifteen who lived off reserves were living below the poverty line, while 65 percent of those above fifteen who lived on reserves were living below the poverty line.

The HTG's petitions conclude that ongoing cultural survival is put in jeopardy by the state's double threat: it refuses to restructure First Nations' relationships to private land and simultaneously insists on "extinguishment treaties" that fundamentally reshape the territorial practices which are intrinsic to their way of life. HTG seeks an alternative that would provide for a future of continued territorial relations.

At the OAS Inter-American Commission of Human Rights (IACHR) admissibility hearings on these filings, the state rejected HTG's petition without compromise. ${ }^{29}$ State lawyers argued that there is no clear evidence of any human rights violations in Canada; that under IACHR rules, the case is inadmissible because the HTG has not exhausted all domestic remedies; and that the IACHR has no jurisdiction or scope of authority to consider 
the issues raised by HTG in the case. The most vigorous element of Canada's defense was the lawyers' touting of the range of domestic remedies available in Canada for resolving issues of Aboriginal property rights, which, they argued, are among the most generous and effective remedies in the world. First, the interest-based treaty negotiation process provides First Nations with the ability to negotiate the recognition and constitutional protection of specific land and cultural rights. The courts provide an alternate option, where First Nations seeking title declarations can bring evidence of historic use and occupancy to a rights-based claims evaluation. Also available in Canada are injunctive relief and judicial review; it is part of the honor of the Crown to consult over potential impacts to Aboriginal rights, and at times to accommodate those rights, even on mere prima facie evidence that, "on the face of it," establishes that the facts of the case may potentially impact a right. Canada also asserted that indigence is not a concern in barring access to these remedies, given that in these cases, the courts can order that First Nations' costs be paid if the issues are compelling.

At best, the options that Canada presented as effective remedies were based on an assertion that using their vision of land claim settlements, the small parcels of land owned and governed by the First Nation could sustain the peoples' way of life. In fact, however, the sweeping "modify-and-release" policy approach that governs cultural rights outside these small First Nations land areas may accommodate state-sponsored development while greatly limiting the practical opportunities for First Nations to actually exercise the cultural rights. Indeed, it is clear that where urban development has taken place, the Hul'qumi'num peoples, previously constrained from practicing their culture in the specific locales of their ancestors, are now becoming fully alienated from cultural practice. Canada's lines of argument at the IACHR worked to obscure issues of scope of authority and scale of land area included in their model of treaty settlement, as well as significant differences between treaty offers made in non-E\&N Railway Grant areas, masking the real ineffectiveness of the domestic remedies that they suggested were available.

In written submissions and at the hearings, HTG responded that in spite of protracted land claims negotiations, there is no prospect that any domestic remedies could be effective in respect to recognizing territorial relationshipsparticularly because in the late 1800 s virtually their entire territory had been granted as private, fee-simple land. ${ }^{30}$ They stressed that the consultation system largely fails to deal with private lands. Other legislative arrangements to recognize and respect Aboriginal property rights, cultural practices, and religious expressions on private lands are lacking. Furthermore, not only are modern-day treaty negotiations notoriously ineffective in respect to private lands, but also, given the poor track record of the Canadian courts in reconciling Aboriginal title and private land, there is little prospect of other means of 
settlement. HTG bolstered their arguments by calling on First Nations from across Canada to submit a remarkable set of amicus curiae legal briefs-reports on the broader issues raised by the case filed by parties who are not a part of the proceedings, or "friends of the court." HTG also submitted affidavits from First Nations, Aboriginal political organizations, leaders, and negotiators that outlined similar experiences. ${ }^{31}$

In late fall of 2009, the OAS Inter-American Commission of Human Rights provided an initial ruling that has potentially opened up the space for dialogue about private lands in indigenous claims. ${ }^{32}$ The IACHR ruled that HTG's petition against Canada on the cumulative impacts of the privatization of Hul'qumi'num traditional territory is admissible for deeper investigation on the merits of the case. The IACHR decided on the strength of prima facie evidence and legal arguments put forward by HTG that it would examine and comment on Canada's alleged violation of rights of the Hul'qumi'num peoples contained in the American Declaration of the Rights and Duties of Man. The specific rights possibly violated are to equality before the law (Article II); profess, manifest and practice a religious faith (Article III); culture (Article XIII); and property (Article XXII). This is the first time that Canada's human rights record has been under such a sweeping review by an international body on substantive indigenous land claims issues.

The IACHR made three highly critical observations of the remedies available to Aboriginal people in Canada. They found that "by failing to resolve the HTG claims with regard to their ancestral lands, the BCTC process has demonstrated that it is not an effective mechanism to protect the right [to property] alleged by the alleged victims." ${ }^{33}$ Examining the government's position that a First Nation can litigate if it does not wish to accept terms offered in negotiation, the IACHR found that "there is no due process of law to protect the property rights of the HTG to its ancestral lands." 34 The IACHR also observed that Canadian court cases on Aboriginal title "do not seem to provide any reasonable expectations of success, because Canadian jurisprudence has not obligated the State to set boundaries, demarcate, and record title deeds to lands of indigenous peoples, and, therefore, in the case of HTG, those remedies would not be effective under recognized general principles of international law." ${ }^{35}$ Finally, critiquing the ineffectiveness of the Heritage Conservation Act, the Commission found that such legislation is "not suitable because they cannot be used to comprehensively and permanently protect all HTG ancestral lands from the actions of their parties because their purpose is not to recognize the HTG's property rights to those lands or the obligation of the State to provide restitution." 36

A modest amount of national press coverage was generated following the admissibility ruling, and the case caught the attention of community groups, 
other First Nations, the UN Permanent Forum on Indigenous Peoples, and Amnesty International, whose secretary general said in a press release, "It is unacceptable that Canada has created such steep barriers to achieving fair and effective redress for the historic and ongoing violation of these rights. We hope that the Inter-American Commission's deliberation on the Hul'qumi'num case will help break the impasse faced by so many indigenous peoples in Canada." ${ }^{37}$ In spite of this public pressure, and HTG's repeated requests to settle the issues through friendly settlement negotiations, Canada refused to change its position with respect to indigenous territories on private lands, pushing HTG to petition the IACHR for a hearing on the merits of the case.

\section{The Merits Hearing}

The process of presenting the substantive merits of a case to the IACHR is quite unlike the onerous process of presenting evidence for Aboriginal title and rights in the domestic courts - a lengthy, costly gambit of proving that cultural practices or specific lands meet the criteria for constitutional protection as Aboriginal rights and title. Rather, the core of HTG's petition on the merits is a fifty-page report with several appendices of affidavits, consultants' reports, and academic publications. In it, HTG presented a case that the ongoing "traditional usages, practices, customs and laws carried out on the land they have owned and occupied since time immemorial" are continually being impacted by the state having created private lands "without prior consultation, restitution or just compensation" in Hul'qumi'num territories. ${ }^{38}$

In 2011 the Hul'qumi'num leadership prepared to return to Washington, DC, to present this argument in a hearing on the merits of their case. The day before the delegation of chiefs, councillors, elders, and legal counsel boarded their planes from Nanaimo to Washington, about one hundred people gathered in the Chemainus Legion Hall. They were there to witness the delegation being lifted up by shulmuxwtsus - the rattlers - an ancient and powerful hereditary ceremony that both gives strength to those for whom it is being performed and honors them with the ancestral rights that the rattle-carriers bear. Witnesses were called by a speaker hired to officiate the event-including myself as the anthropologist traveling with the delegation-and were tasked with remembering the work about to unfold before the eyes of the world. At the end of an hour-long procession of hereditary rattles and sacred songs, two elders stood up to attend the delegation with some advice. "You have to walk with one mind," we were told; "the people at home want you to succeed. The chiefs have travelled in the past. This is not new. You are going to speak out for us. Because we are related, because we are one, because we speak together." These words were a salve for the pressure the HTG-member First Nations have 
been under in their collective efforts to formulate an aggregated self-governing body. 39 Particularly challenging has been the state's language of "overlapping claims," which has been costly and divisive in recent years. ${ }^{40}$ With the foresight so typical of elders, this advice foreshadowed a central issue to come.

On the night before the merits hearing, in a private room in Morton's Steakhouse in Washington, legal counsel made their final preparations with the chiefs. Robert A. Williams Jr., a remarkable and dynamic law professor, charted out the key arguments to be made. As the delegation worked late into the night, other supporters who had joined the group shared words of encouragement and prayer. A representative of Amnesty International offered his views that the evidence of continued government-permitted burial desecration and denial of access to hunting-fishing-gathering practices are clearly human rights violations and that exposing Canada's smug human rights record to the world had international significance. A supporter from Lawyers' Rights Watch pointed out that the continued preferential treatment of private landowners over Aboriginal property rights is clearly discriminatory. Chief Doug White III, a dynamic leader of a neighboring First Nation that was also impacted by the E\&N Railway Grant, applauded the HTG chiefs for standing up to "the ugly denials of Canada," and spoke of his life goal of seeing all Coast Salish peoples working together as a bloc on key issues like these.

At the merits hearing itself, a little more than an hour passed from start to finish. ${ }^{41}$ Robert Williams and Elder Luschiim Arvid Charlie from Hul'quminum Treaty Group contained their articulate and concise presentations to the allotted twenty-five minutes. Canada's response reiterated many arguments from previous hearings: that the case should be deemed inadmissible, that the existing negotiation process provides a more-than-adequate domestic remedy which other First Nations are accepting, and that if HTG members believe they have a valid claim, they could take Canada to court. Then, revealing Canada's ace card, a representative argued that 75 percent of the claimed traditional territory is also claimed by eight other First Nations, so HTG may not have adequate proof of its title claims. The state produced a map of extensively overlapping claims within the Salish Sea area, which the representative said illustrated that there was no way to see if Canada was violating rights, as a properly brought case with proof of exclusive Aboriginal title had never been run. ${ }^{42}$ In its written submissions, Canada elaborates that the claims of parties which overlap the HTG's claimed traditional territory-eighteen other First Nations being represented by eight Aboriginal groups-demonstrate conclusively, if nothing else, that claims are at issue in this petition, not established rights with defined scope. ${ }^{43}$ Underscoring that "an objective determination of the extent of the traditional territory of the HTG, if any, beyond their reserve lands, is not being pursued by HTG" in the courts, 
Canada concludes that "the alleged violations of Article XXIII, the Right to Property must fail because the HTG have not substantiated the location or extent of their claimed property rights." 44

Canada's attempt to obviate state obligations towards Hul'qmi'num peoples' cultural practices-changing the focus to unresolved "overlapping claims" that negate the exclusivity of title-has become the hindrance of the case. It is a clever sleight of hand that diverts attention away from the pressing issues that Hul'qumi'num people have taken pains to point out-that private lands make ongoing cultural practices difficult to continue within an unrecognized system of customary tenure-and draws attention instead to Canada's own aggressive stance that any property claims Hul'qmi'num people may have are contested and may not even exist. In this IACHR case, the state's argument rests on a basic denial of indigenous territorial relations, instead taking up a narrow view which sees property only through the domestic court's onerous burden of proof for Aboriginal title. 45 The state conveniently designs land claims processes which insist that indigenous communities represent their territories with simple boundary lines; yet when the resulting territorial representations of neighboring communities overlap, the state denies having obligations to indigenous claimants precisely because simple boundary lines inadequately abstract their complex territoriality ${ }^{46}$

To the Coast Salish leadership, these arguments are not new. In my experience, the state has raised issues of "overlap" again and again as a way to avoid addressing fundamental concerns over accommodating indigenous cultural practices or recognizing indigenous property and jurisdiction. Indeed, HTG legal counsel responded to these assertions around "exclusivity" by working to reframe the language used. In a written response to the commission, they clarified that HTG has never made a claim to completely exclusive rights through the territory, instead revealing how Coast Salish customary law recognizes the network of property rights and interests in lands and resources that are shared with or excluded from other indigenous groups in the region. ${ }^{47}$ Legal counsel for Hul'qumi'num Treaty Group went on to argue that Canada's position on overlaps is an "untethered legal absurdity." As shown by Inter-American system precedents in the Awas Tingni and Maya Belize cases, overlapping claims do not shift the duty from the state to indigenous peoples to resolve land claims before the state actually acts to protect indigenous property rights. The Commission's position is that the statute must provide "a consensual investigation into flexible models" to recognized indigenous property while "guarantee[ing] continuity of the different uses of territory by indigenous peoples, in all their complexity." 48

Though the IACHR has not yet made its final ruling on the merits of the case, the Hul'qumi'num leadership hope that the full complexity of their 
territorial relations and aspirations will be appreciated by the Commission. Their hope is that IACHR will direct Canada to provide relief for the members of the HTG, but also for all of the other First Nations whose territories have been similarly impacted by lack of recognition of indigenous property rights.

It is clear that the state actors are invested in discourses that do not closely attend to these indigenous social and political realities. On occasions when the standard colonial discourse of terra nullius is not promulgated, state actors echo the Aboriginal title tests established by domestic courts, which narrow indigenous property to exclusively occupied, "site-specific" locales, effectively reducing the potential scope and breadth of indigenous ownership and jurisdiction. ${ }^{49}$ The domestic legal test requiring Aboriginal title claimants to establish "exclusive occupation ... at the time of sovereignty" draws on English common-law traditions that envisage exclusivity as emerging from "the construction of dwellings, cultivation of the land, the enclosure of fields, and the regular use of well-defined tracts." 50 While the Supreme Court in the Delgamuukw decision did signal that exclusivity must "take into account the context of the aboriginal society at the time of sovereignty," scholars like Burke have observed that there are likely limits to how far the construction of "exclusive occupancy" can be stretched "semantically and metaphysicallyuntil from the traditional Western view, it no longer signifies its original referent." 51 From Canada's arguments at the IACHR, it is clear that the principles of indigenous land tenure described above likely stray too far from this Western vision.

The state continues to extend its vision of property in the text of modernday land claim settlements by developing entirely new categories of land ownership - treaty settlement land-that harden the "exclusivity" distinctions expressed in common-law Aboriginal title. ${ }^{52}$ Here, we more clearly see Canada's interest in exclusivity: exclusivity neatly clarifies which legal personthe collective members of a First Nation-has property rights to which the state may owe a duty, and precludes having multiple duties to two or more First Nations if each has title to the same land. Such settlement agreements are largely consistent with the stridently neoliberal proposals of Flanagan, Alcantara, and le Dressey to create a framework that would turn other First Nations lands into private "fee simple" land holdings that could leverage equity in conventional real estate markets. ${ }^{53}$ All of these state mechanisms promote and extend the language of exclusivity, boundedness, statehood, and private property onto indigenous relationships to land. They work to maximize the certainty and effectiveness of state jurisdictions and systems of property, enabling the development of land, resources, and community. 


\section{REFRAMING “OVERLAPS” AND INDIGENOUS TERRITORY}

How did these abstractions of indigenous territoriality, particularly the powerful concept of "overlap," come to undermine indigenous efforts toward territorial recognition? Are there better ways to represent indigenous territorial relations in claims processes?

This "overlap problem" has multiple sources. The popular press often suggests that indigenous groups are simply making overly large claims as a negotiating tactic and "overlaps" naturally ensue. However, it is clear that more compelling and complex factors are at play. The cartographic abstraction of a single boundary line to represent the whole of indigenous territorial, jurisdictional, and property relations is clearly inadequate. These cartographic abstractions of indigenous territories have, as anthropologist Paul Nadasdy cogently observed, come to be a "common-sense" representation of indigenous political orders that envision "the world as divided up among political entities, each exercising jurisdiction over discrete mutually exclusive territories separated by linear borders." ${ }^{54}$ These "common-sense" notions of territory that are charted out for indigenous land and governance negotiations "are not simply formalizing jurisdictional boundaries among pre-existing First Nations polities ... they are mechanisms for creating the legal and administrative systems that bring those polities into being." The language of "overlap" emerges from the creation of these political institutions and the ensuing "ethno-territorial identities and corresponding nationalist sentiments." 55

The consequences of these abstractions continue to be among the problems most bedevilling Aboriginal governance today. ${ }^{56}$ As both colonialist administration and self-determination have reconstituted Canadian indigenous communities, in many cases, problems in territorial relationships have become exacerbated. 57 The Senate Standing Committee on Aboriginal Affairs recently commented that there is "no clear mechanism for resolving overlaps" in treaty negotiations. ${ }^{58}$ The BC Treaty Commission has identified resolving overlapping claims to be the central barrier Aboriginal communities face, while at the same time federal and provincial governments have constrained mandates and limited political will to reach settlements. ${ }^{59}$ These are pressing and intractable problems because the solutions demanded by the state-the delineation of contiguous, bounded, exclusive territories - require indigenous peoples to fundamentally reimagine both territory and territorial relations.

For indigenous peoples who engage in these representational practices of framing territorial claims, as well as the collaborators and allies who work with them, it is a challenge to translate local understandings of land tenure. Working in Australia, Povinelli has observed that "most practicing land claims lawyers and anthropologists know the law imposes conditions 
on the performance of local culture and that these conditions are based on abstracted anthropological models that do not fit any particular Aboriginal group, culture, or practice perfectly." 60 This is the case with respect to many Coast Salish efforts to map territorial claims. Even though their maps highlight connections among local groups-usually Indian bands or umbrella tribal groups-through the depiction of "traditional territory" boundary lines, the actual complexity of kin-based territorial organization is difficult to represent cartographically. Moreover, the community composition of self-identifying nations varies from small villages to aggregated multi-community nations, and these different political orders frequently subsume and transcend a cartography of neatly contiguous boundaries ${ }^{61}$ For example, indigenous nations have aggregated without all ancestral peoples gaining membership, Indian band administrations have been formed by the state in many cases without regard for the interconnections between communities, and indigenous property and tenure systems have become disrupted by colonial settlement and the exercise of state jurisdictions. ${ }^{62}$ Changes in territoriality over time, influenced by both colonial processes and local sociopolitical realities, further complicate the drawing of fixed, exclusive boundaries. Even geomorphological processes have had implications for overlapping claims in the boundary-setting work of state cartography. ${ }^{63}$ Consequently, the complex nature of contemporary indigenous territoriality is poorly served by the current practice of drawing contiguous territories marked by singular, "exclusive" boundary lines. ${ }^{64}$

Nonetheless, indigenous participants in these processes continue to generate these representations, and the boundary lines they generate have significance. In the context of Coast Salish land tenure, for instance, territoriality may be most plainly understood with respect to subsistence practices and other itineraries of everyday life that connect people to territory through residence, ancestry, and kin.65 Navigating territoriality requires both an intimate knowledge of local places and of one's kinship network. Membership in a household or village community of residence allows access to productive resource locations. As encountered in ongoing spiritual and ritual practices, the ancestors' continued presence demands ongoing relationships of respect and reciprocity. Individuals navigate their access to territories through their residence and family ties, seeking permissions, shifting residences, and participating in the rigors of community and cultural life. Marriage ties allow in-laws to play host to affinal kin, particularly in the common situation of marrying outside of the village. ${ }^{66}$ To host in-laws from distant villages who wish to use resources not locally available, and to be thanked by guests with gifts of food or wealth, whether at the time or later during potlatches and related events, forms a system of sharing and reciprocity of the kind discussed by Tim Ingold. ${ }^{67}$ 
Although indigenous land tenure systems may potentially be "opened up" by roads, powerboats, technologically mediated communication, and state harvest license and management schemes, community members continue to recognize territorial practices and protocols. In expressing their frustrations about the language of "overlaps" in land claims, elders emphasized over and over the importance that knowledge of kinship connections holds in traveling throughout this territorial system. Florence James, a respected holder of cultural knowledge from Penelakut, shared her views on how, in this traditional land tenure system, kinship connections transcend the language of overlaps.

And we, we know all our families traveled together and went from island to island for their foods. We were all Hul'qumi'num peoples at one time; we didn't have differences in community. Everybody loved and cared for one another. And that's a teaching. We don't make each other different because of our bloodline. And we're families that are made up of all different families. You know, make up the tree and every branch doesn't come from one place. So the people always knew each other and knew their family tree in the oral history....

And everyone didn't make each other's community different; they were all one peoples. Today we use nuts'a'maat and that represents "one thought," that word. And so nuts'ámaat.

But we are not "one thought." They were all different, separated communities [put] on reserves. And [today] everyone's learned "oh, you're from there, you can't come here" and "you can't do this and say that" and "it never used to be like that." And so that's why they had that word nuts'a'maat. Lots of meaning, that one....

Now, it's not known. Everybody seems to be, "divide and conquer," that's what is being used.... And yet my grandfather, he had family from Cowichan, they had a longhouse there. And they had family in Saanich. They had family, his in-laws, the wife was from Nanaimo. And the man came from here that made my great grandmother and so that's the way our family tree is made up....

And you're supposed to share and look after each other, love one another, raise your children that way and so they won't carry on without that beautiful knowledge of the ancestry. You have to keep it alive. That's what my grandfather said. If you're doing the wrong things, correct yourself ... remember your own ways and try to get back to it.

James's expansive vision illuminates Coast Salish territorial understandings: one is both from a place and connected to others through family. By evoking that knowledge and respecting those family connections, a world of possibility opens up. Interestingly, and perhaps most locally effective in a context where Salishan languages are highly endangered, fluent Native language speakers such as Florence James have been working to infuse political discourse with indigenous concepts like nuts'a'maat. As an adjective used 
to describe the qualities of a group that has a sense of being together as one, while recognizing individual distinctness within the group- "being together as one" as opposed to "being one"-nuts'a'maat has become a particularly charged word, one that now even nonfluent speakers have incorporated into their political oratory. The terminology provides a powerful means of rethinking and reframing words such as "overlapping claims" and "exclusivity" Such an idea resonates with peoples' other experiences such as being in the big house, taking part in canoe races, and working together for major events. It also holds more appeal than "proving" the territorial rights of one indigenous people over those of another by devising increasingly clever appeals to existing legal doctrine.

As Florence James shared, "thinking the same" is not equivalent to "being the same." Despite the recognition of wide networks of kin and an ethic of sharing, this is not an open-area-commons property system; people do not play host to everyone, all the time ${ }^{68}$ Community members have the right to restrict distant relatives by marriage or non-kin outsiders from trespassing on areas owned by household or village groups. Enforcement against trespassers or those who have overstayed their welcome includes a whole range of remedies: public or political pressure, potlatch reprisals, and occasionally violence. Though in the last fifteen years a number of disputes have arisen over trespassing by unwelcome individuals who were harvesting, perhaps not surprisingly, disputes have most commonly arisen when governments are involved. In situations where consequential governmental monetary or jurisdictional outcomes have been at stake, at times First Nations representatives have also evoked the language of "exclusivity" and "overlap." For instance, the provisions of the Tsawwassen Final Agreement, which extended harvesting and other rights to the Gulf Islands, sparked a number of legal actions by neighboring First Nations. Intense but private debates have also been sparked about which First Nation should be involved in decisions on managing disturbed ancient human remains in the Gulf Islands. I have also witnessed a number of debates on which names and histories of local places should be recognized or acknowledged in public or government publications when place-names in more than one language exist. In language revitalization efforts, remembered names in a neighboring language may be "borrowed" and put into a local orthography, making those places "belong" to the other First Nation. In all of these cases, however, maintaining respectful relations has been the desired outcome even when conflict is apparent. Judging from these experiences and discourses, in practice, territories are spaces for strategically activating networks of kin just as much as they are notional boundaries of ancestral village groups, Indian bands, or First Nations. 


\section{Conclusions: The POWER of ReCOGNITION}

In 2013, an elected local government official from Gabriola Island discussed in a CBC radio interview the regional district's debates on whether it should explicitly recognize the traditional territory of the local First Nation when opening their meetings. His territorial recognition motion had been debated and rejected by a majority of the board the night before. One member's rationale for rejection was that the act of recognizing indigenous territories would be less significant if performed every day instead of only on special occasions; others observed that there might be a further problem because a dozen overlapping First Nations fell within the local government's jurisdiction. This seemingly banal local government debate illuminates just how problematic the idea of "territory" continues to be for settler authorities. Because even a largely symbolic gesture becomes loaded with the uncertainties of ownership and governance that such a recognition of territory implies, the simplest solution is to continue to deny recognition by appealing to the powerful logic of "overlaps."

Elizabeth Povinelli encourages anthropologists, activists, and lawyers to find places in the law for the recognition of "local traditional social organization [and] not to use an outdated anthropological model to discipline the local." 69 To thus find a place in the law for local social tradition, she argues, creates space for the truth to be understood and the spirit of the law to be fulfilled. These are important observations. My intention in this article is not to undermine territorial claims by dismissing boundary-making practices, but to help illuminate how these practices provoke social and political complications, and also to make sense of territorial claims in Coast Salish terms. In turn, I hope this can promote understanding of the importance of recognizing Coast Salish laws and ways of relating to place.

In addition to the soft power of international law, the human rights lobby, and the media, these Coast Salish communities look to the strengths of the elders and the leaders who have gone before them, and continue to mobilize spirit power and cultural power in order to fundamentally challenge bedrock state institutions of private property, regulatory governance, and territorial claims settlement. While many challenges exist, there is some cause for optimism that the wisdom of expanding the limited vision of the state to include indigenous notions of territoriality will prevail. Even though state-defined Aboriginal title and rights discourses continue to have the potential to divide, the emerging indigenous governance and human rights frameworks may be key to recognizing and incorporating indigenous territoriality, empowering indigenous peoples' visions of the future. 


\section{Acknowledgments}

This research would not have been possible without the support and collaboration of the Hul'qumi'num Treaty Group. My thanks and acknowledgments go to the HTG Board of Directors, the HTG Elders Committee, and to Joey Caro, Robert Morales, Renee Racette, M. J. Churchill, Eric McLay, and Lea Joe, all of whom contributed in many ways. This article's interpretations and analysis are my own, and are not made with the intention to prejudice any Aboriginal rights, Aboriginal title, or other claims. I also thank the reviewers and editors, who helped me to clarify and amplify the significance of this case. Any errors that may have been made in this paper are mine.

\section{NOTES}

1. State visions of indigenous territories have been extensively discussed in the literature. Useful authorities include: Tim Ingold, "Territoriality and Tenure: The Appropriation of Space in Hunting and Gathering Societies," The Appropriation of Nature: Essays on Human Ecology and Social Relations, ed. Tim Ingold (Iowa City: University of Iowa Press, 1987), 130-64; Richard Overstall, "Encountering the Spirit in the Land: 'Property' in a Kinship-Based Legal Order," Despotic Dominion: Property Rights in British Settler Societies, ed. John McLaren (Vancouver: University of British Columbia Press, 2005), 22-49; Colin Scott, "Property, Practice and Aboriginal Rights among Quebec Cree Hunters," Hunters and Gatherers 2: Property, Power and Ideology, ed. Tim Ingold, David Riches and James Woodburn (Oxford: Berg, 1988), 35-51; William Wonders, "Overlapping Native Land Claims in the Northwest Territories," American Review of Canadian Studies 18, no. 3 (1988): 359-68.

2. There is extensive scholarship on the way the state has worked to convert indigenous land tenure into state forms of property. Useful examples include: Gurston Dacks, "British Columbia after the Delgamuukw Decision: Land Claims and Other Processes," Canadian Public Policy / Analyse de Politiques 28, no. 2 (2002): 239-55; Kent McNeil, "Aboriginal Title and the Supreme Court: What's Happening?," Saskatchewan Law Review 69, no. 2 (2006): 281-308; Dwight Newman and Danielle Schweitzer, "Between Reconciliation and the Rule(s) of Law: Tsilhqot' in Nation v. British Columbia," University of British Columbia Law Review 41 (2009): 249-76; Brian Slattery, "Some Thoughts on Aboriginal Title," University of New Brunswick Law Journal 48 (1999): 19-40.

3. Brian Egan has written several useful pieces on the history of colonial land grabs on southeast Vancouver Island, including From Dispossession to Decolonization: Towards a Critical Indigenous Geography of Hul'quminum Territory, PhD diss. (Carleton University, 2008); and "Sharing the Colonial Burden: Treaty-making and Reconciliation in Hul'qumi'num Territory," The Canadian Geographer 56, no. 4 (2012): 1-21.

4. Mario Blaser, Harvey Feit, and Glenn McRae, In the Way of Development: Indigenous Peoples, Life Projects, and Globalization (London: Zed Books, 2004).

5. Although there has been some scholarly attention on the issue of overlapping claims in Canada, the literature is relatively sparse. Significant works include: Nigel Banks, "Marshall and Bernard: Ignoring the Relevance of Customary Property Laws," University of New Brunswick Law Journal 55 (2006): 120-34; Brian Burke, "Left Out in the Cold: The Problem with Aboriginal Title Under Section 35(1) of the Constitution Act, 1982 for Historically Nomadic Aboriginal Peoples," Osgoode Hall Law Journal 38, no. 1 (2000): 1-38; Paul Nadasdy, "Boundaries among Kin: Sovereignty, the Modern Treaty Process, and the Rise of Ethno-Territorial Nationalism among 
Yukon First Nations," Comparative Studies in Society and History 54, no. 3 (2012): 499-532; Arthur Ray, "Constructing and Reconstructing Native History: A Comparative Look at the Impact of Aboriginal and Treaty Rights Claims in North America and Australia," Native Studies Review 16, no. 1 (2005):15-39; and Peter Usher, "Environment, Race and Nation Reconsidered: Reflections on Aboriginal Land Claims in Canada," The Canadian Geographer 47, no. 4 (2003): 365-78.

6. William C. Wonders, Overlapping Land Use and Occupancy of Dene, Metis, Inuvialuit and Inuit in the Northwest Territories (Ottawa: Indian and Northern Affairs Canada, 1983).

7. These cases are cited as Chief Allan Apsassin v. Attorney General of Canada, 2007 BCSC 492; Cook v. Minister of Aboriginal Relations and Reconciliation, 2007 BCSC 1772; Cowichan Tribes v. Ministry of Aboriginal Relations and Reconciliation, SCBC Vancouver Registry No. S-076136; Gitanyow First Nation v. Canada, 1998, CanLII 5403 (BC S.C.) 1998-11-24; Gitanyow First Nation v. British Columbia, 1999 BCCA 343 (CanLII) 1999-06-01; Gitanyow First Nation v. Canada, 1999 CanLII 6130 (BC S.C.) 1999-07-08; Luuxhon et al v. HMTQ, et al. and Nisga'a Nation, 2000 BCSC 1332 (CanLII) 2000-09-26; Luuxhon v. Canada, 1998 CanLII 4198, 4460 (BC S.C.) 199806-17; Luuxhon v. Canada, 1999 CanLII 6180 (BC S.C.) 1999-03-23; Semiabmoo First Nation v. Minister of Aboriginal Relations and Reconciliation, SCBC, Vancouver Registry No. S-074496; Sencoten First Nations v. Minister of Aboriginal Relations and Reconciliation, SCBC Vancouver Registry No. S-074887; Tseshaht First Nation v. Huu-Ay-Abt First Nation, 2007, BCSC 1141.

8. Examples include the Mathias case, cited as Squamish Indian Band v. Canada, [2000] F.C.J. No. 1568 (F.C.T.D.), and Delgamuukw v. British Columbia, [1997] 3 S.C.R. 1010 (S.C.C.). See Sandra Gogal, Richard Riegert, and JoAnn Jamieson, "Aboriginal Impact and Benefit Agreements: Practical Considerations," Alberta Law Review 43, no. 1 (2005): 129-57.

9. Examples of scholarship on overlapping claims in New Zealand and Australia include: Simon Correy, "The Reconstitution of Aboriginal Sociality through the Identification of Traditional Owners in New South Wales," The Australian Journal of Anthropology 17, no. 3 (2006): 336-47; Craig Jones, "Aboriginal Boundaries: The Mediation and Settlement of Aboriginal Boundary Disputes in a Native Title Context," National Native Title Tribunal Occasional Papers Series 2, no. 16 (2002): 1-14; Peter Sutton, "The Robustness of Aboriginal Land Tenure Systems: Underlying and Proximate Customary Titles," Oceania 67, no. 1 (1996): 7-29; Peter Sutton, "Aboriginal Country Groups and the 'Community of Native Title Holders,"' National Native Title Tribunal Occasional Papers Series, no. 1 (Perth: National Native Title Tribunal, 2001).

10. Elizabeth Povinelli, The Cunning of Recognition (Durham NC: Duke University Press, 2002).

11. Johnny Mack, "Hoquotist: Reorienting through Storied Practice," Narratives of Contact and Arrival in Constituting Political Community, ed. Hester Lessard, Rebecca Johnson and Jeremy Webber (Vancouver: University of British Columbia Press), 298.

12. Povinelli, Cunning.

13. Mario Blaser, "Life Projects: Indigenous Peoples' Agency and Development," In the Way of Development: Indigenous Peoples, Life Projects, and Globalization, ed. Mario Blaser, Harvey A. Feit, and Glenn McRae (London: Zed Books, in association with International Development Research Centre, 2004): 27-44; Arturo Escobar, Territories of Difference: Place, Movements, Life, Redes (Durham: Duke University Press, 2008); Harvey Feit, "James Bay Crees' Life Projects and Politics: Histories of Place, Animal Partners and Enduring Relationships," In the Way of Development, 92-110.

14. Indian and Northern Affairs Canada, Canada Takes Action to Support Progress in the BC Treaty Process, March 2010, CIDM 2873990 (Ottawa: Indian and Northern Affairs Canada, 2010), http://www.fvrd.bc.ca/InsidetheFVRD/MeetingsAgendasMinutes/AboriginalRelationsCommittee/ Archived\%20Agendas/2010\%2005\%2026\%20Treaty\%20Advisory\%20Committee/Item\%2004\%20 2-Canada\%20Action\%20Plan.pdf.

15. Egan, Sharing the Colonial Burden. 
16. Halalt First Nation v. British Columbia (Environment), 2011 BCSC 945; Halalt First Nation v. North Cowichan (District), 2011 BCCA 544; Halalt First Nation v. British Columbia (Environment), 2012 BCCA 191; Halalt First Nation v. British Columbia, 2012 BCCA 472; Chief James Robert Thomas, Chief James Robert Thomas, aka Sulsimutstun, et al. v. R., et al., 2013 CanLII 42520 (SCC).

17. Meike Holst, Elmar Plate and Robert Bocking, Alienation of Traditional Clam Harvesting within the Hul'quminum Territories, report prepared for Hul'qumi'num Aboriginal Aquatic Resource and Oceans Management Group, LGL Report EA3300, 2011, report on file, Hul'qumi'num Treaty Group Library and Archives, Ladysmith, BC.

18. Brian Thom, "Disagreement-in-Principle: Negotiating the Right to Practice Coast Salish Culture in Treaty Talks on Vancouver Island, BC," New Proposals: Journal of Marxism and Interdisciplinary Inquiry 2, no. 1 (2008): 23-30.

19. Carole Blackburn, "Producing Legitimacy: Reconciliation and the Negotiation of Aboriginal Rights in Canada," Journal of the Royal Anthropological Institute 13, no. 3 (2007): 621-21; and Mack, "Hoquotist."

20. American Declaration of the Rights and Duties of Man, reprinted in Basic Documents Pertaining to Human Rights in the Inter-American System, OAS/Ser.L/V/I.4 Rev. 9 (2003); 43 AJIL Supp. 133 (1949), http://www.oas.org/xxxivga/english/reference_docs/Derechos_Hombre.pdf.

21. Robert A. Williams Jr., S. James Anaya, Angela C. Poliquin, and Jacklyn Hartley, Petition to the Inter-American Commission on Human Rights submitted by the Hul'quminum Treaty Group against Canada (Ladysmith, BC: Hul'qumi'num Treaty Group, 2007), http://www.law.arizona.edu/iplp/ outreach/htg/documents/HTG\%20Petition\%20-\%205-09-07.pdf.

22. Ibid., 12 .

23. Ibid., 34,8 .

24. Williams, et al., Hul'quminum Treaty Group Observations on the Merits, Appendix 1: The Hul'qumi'num Atlas, document on file, Hul'qumi'num Treaty Group Library and Archives, Ladysmith, $\mathrm{BC}$.

25. Robert A. Williams, Jr., Seánna Howard and Mary Gus, Hul'quminum Treaty Group Observations on the Merits of the Case, Inter-American Commission on Human Rights, in Relation to Case no 12.734 (Canada) (Ladysmith, BC: Hul'qumi'num Treaty Group, 2010), 7, document on file, Hul'qumi'num Treaty Group Library and Archives, Ladysmith, BC.

26. Of course, possible solutions are complex and various. For example, the government could buy the land and return it to HTG; they could give the sum to HTG to go land-shopping with; or they could establish a trust fund for the long-term acquisition of lands. In fact, the HTG has made many flexible proposals in this regard, but governments have not wanted to talk about cash amounts anywhere close to this kind of value.

27. Robert A. Williams, Jr., S. James Anaya, and Jacklyn Hartley, Response to Request for Additional Information, the Inter-American Commission on Human Rights, submitted by the Hul'quminum Treaty Group, P-592-07 against Canada (Ladysmith, BC: Hul'qumi'num Treaty Group, 2007), Appendix 29, document on file, Hul'qumi'num Treaty Group Library and Archives, Ladysmith, BC.

28. From "Presentation to the Inter-American Commission on Human Rights in Relation to Petition No. P-592-07 (Canada) submitted by the Hul'qumi'num Treaty Group against Canada," October 2009, document on file, Hul'qumi'num Treaty Group Library and Archives, Ladysmith, BC; Robert A. Williams, Jr., Seánna Howard, and Renee Racette, Petitioner's Response to Canada's Observations on the Merits in relation to Case No. 12.734 submitted by the Hul'quminum Treaty Group to the Inter-American Commission on Human Rights (Ladysmith, BC: Hul'qumi'num Treaty Group, May 2011), 27-29, document on file, Hul'qumi'num Treaty Group Library and Archives, Ladysmith, BC. 
29. From Oral Submission of Canada to the Inter-American Commission on Human Rights on the Inadmissibility of the Petition of the Hul'quminum Treaty Group, Case No. P-592-07 (October 28, 2008), http://www.cidh.oas.org/Audiencias/133/B26HulquminumTreatyGroupCanada.mp3, accessed 03 October 2014; and March 9, 2009, http://www.cidh.org/Audiencias/134/20.\%20P\%20592\%20 07\%20y\%20MC\%20110\%2007\%20Hul\%20qumi\%20num\%20Treaty\%20Group\%20Canada.mp3.

30. Hul'qumi'num Treaty Group raised these points repeatedly in their admissibility submissions. See, for example, Robert A. Williams, Jr., and S. James Anaya, Response to Second Request for Additional Information, the Inter-American Commission on Human Rights, Submitted by the Hul'quminum Treaty Group P-592-07 against Canada (Ladysmith, BC: Hul'qumi'num Treaty Group, November 2007), and Reply to Submission of Canada to the Inter-American Commission on Human Rights, Submitted by the Hul'quminum Treaty Group P-592-07 (Ladysmith, BC: Hul'qumi'num Treaty Group, July 2008).

31. The amicus curiae were submitted to the Inter-American Commission on Human Rights by the individual First Nations organizations and individuals. These included Ahousaht First Nation, the Assembly of First Nations, the First Nations Summit, Nunavut Tunngavik Inc., the Union of British Columbia Indian Chiefs, Laich-Kwil-Tach Treaty Society, British Columbia Assembly of First Nations, Stó:lō Tribal Council and Gitanyow Hereditary Chiefs, Okanagan and Secwepemc First Nations. Affidavits were given by the Chief of the Westbank First Nation and the Chief Treaty Negotiator for the Westbank First Nation, legal counsel for the Sliammon and Snuneymuxw First Nations, among others. These are cited by Hul'qumi'num Treaty Group in oral presentations during the March 2009 admissibility hearing, and in Robert A. Williams Jr. and Seánna Howard, Summary of Presentation to the Inter-American Commission on Human Rights During 134th Period of Sessions in relation to Petition No. P-592-07 (Canada) Submitted by the Hul'quminum Treaty Group (Ladysmith, BC: Hul'qumi'num Treaty Group, March 2009), document on file, Hul'qumi'num Treaty Group Library and Archives, Ladysmith, BC.

32. The Inter-American Commission on Human Rights, Report No 105/09, Petition 592-07 Admissibility, Hul'quminum Treaty Group v. Canada, http://www.cidh.oas.org/annualrep/2009eng/ Canada592.07eng.htm.

33. Ibid., para. 37.

34. Ibid.

35. Ibid., para. 41.

36. Ibid., para. 43.

37. Canada NewsWire, "Hul'qumi'num Treaty Group Opposing Proposed 1 Billion Dollar Sale by TimberWest without Consultation," May 12, 2011, http://cnw.ca/61V81, accessed 03 Oct 2014.

38. Robert A. Williams, Jr., Seánna Howard and Mary Gus, "Hul'qumi'num Treaty Group Observations on the Merits of the Case," Inter-American Commission on Human Rights in Relation to Case No. 12.734 (Canada), (Ladysmith, BC: Hul'qumi'num Treaty Group, January 2010), document on file, Hul'qumi'num Treaty Group Library and Archives, Ladysmith, BC; quotations are from paragraphs 12 and 2 .

39. Brian Thom, "The Anathema of Aggregation: Towards 21st Century Self-Government in the Coast Salish World," Anthropologica 52, no. 1 (2010): 33-48.

40. Brian Thom, "The Paradox of Boundaries in Coast Salish Territories," Cultural Geographies 16, no. 2 (2009): 179-205.

41. The Inter-American Commission on Human Rights hosts an online video of the merits hearing, "Case 12.734-Hul'qumi'num Treaty Group, Canada," http://www.oas.org/OASPage/ videosasf/2011/10/102811_PV_V1_9am.wmv, accessed 03 October 2014. Pictures of the hearing were taken by the IACHR and posted online, http://www.flickr.com/photos/oasoea/ sets/72157627872575033/. 
42. A version of this map, though different than the actual one presented at the hearing, can be found in Submission of Canada to the Inter-American Commission on Human Rights on the Merits of the Petition of the Hul'quminum Treaty Group, Case No 12.734 (Ladysmith, BC: Hul'qumi'num Treaty Group, August 2010), Annex C, document on file, Hul'qumi'num Treaty Group Library and Archives, Ladysmith, BC.

43. Ibid., 20; emphasis in original.

44. Supplemental Submission of Canada to the Inter-American Commission on Human Rights on the Merits of the Petition of the Hul'quminum Treaty Group, Case no. 12.734 (Ladysmith, BC: Hul'qumi'num Treaty Group, November 2010), 73); see also Submission of Canada August 2010, 32 (emphases in originals).

45. See, for instance, Ronald Niezen, "Culture and the Judiciary," The Rediscovered Self: Indigenous Identity and Cultural Justice (Montreal: McGill-Queen's University Press, 2009), 66-91; and Kent McNeil,"The Onus of Proof of Aboriginal Title," Osgoode Hall Law Journal 37, no. 4 (1999): 775-803.

46. Thom, Paradox.

47. Robert A. Williams, Jr., Seánna Howard, and Renee Racette, Petitioner's Response to Merits Hearing and Supplemental Submission of Canada in Relation to Case No. 12.734 Submitted by the Hul'quminum Treaty Group to the Inter-American Commission on Human Rights (Ladysmith, BC: Hul'qumi'num Treaty Group, December 2011), 35, document on file, Hul'qumi'num Treaty Group Library and Archives, Ladysmith, BC.

48. Organization of American States Inter-American Commission on Human Rights, Indigenous and Tribal Peoples' Rights over their Ancestral Lands and Natural Resources: Norms and Jurisprudence of the Inter-American Human Rights System (OEA/Ser.L/V/II., Doc. 56/09, December 2009), 49, http://www.oas.org/en/iachr/indigenous/docs/pdf/AncestralLands.pdf.

49. Michael Asch, "From Terra Nullius to Affirmation: Reconciling Aboriginal Rights with the Canadian Constitution," Canadian Journal of Law and Society 17, no. 2 (2002): 23-39.

50. Delgamunkw v. R, 1101.

51. Ibid., 1104; Burke, Left Out in the Cold, 30.

52. Brian Egan, "Towards Shared Ownership: Property, Geography and Treaty Making in British Columbia," Geografiska Annaler: Series B, Human Geography 95, no. 1 (2013): 35-50.

53. Tom Flanagan, Christopher Alcantara, and André Le Dressay, Beyond the Indian Act: Restoring Aboriginal Property Rights (Montreal: McGill-Queen's University Press, 2010).

54. Nadasdy, Boundaries among Kin, 501.

55. Ibid., 503 (emphasis in original).

56. Murray Brown, "Negotiating Protocol Agreements for Treaty Overlap Areas," Overlapping Territorial Claims: Models for Dispute Resolution: Proceedings of the 2009 National Aboriginal Law Conference, 12-13 June 2009, Victoria, Ottawa, ed. Canadian Bar Association, 2009), np; Christopher Devlin and Tim Thielmann, "Overlapping Claims: In Search of 'A Solid Constitutional Base," Overlapping Territorial Claims, np; Mark East, "Addressing Overlapping Claims in the BC Treaty Process: A Federal Perspective," Overlapping Territorial Claims, np; and Greg McDade, "Overlaps: Tools for Resolution," Overlapping Territorial Claims, np.

57. Peter Elias, "Anthropology and Aboriginal Claims Research," Anthropology, Public Policy and Native Peoples in Canada, ed. Noel Dyck and James B. Waldram (Montreal: McGill-Queen's University Press, 1993), 233-70; Thom, Anathema; Peter Usher, "Common Property and Regional Sovereignty: Relations Between Aboriginal Peoples and the Crown in Canada," The Governance of Common Property in the Pacific Region, ed. Peter Larmour (Canberra: Australian National University, 1997), 365-78. 
58. Standing Senate Committee on Aboriginal Peoples, "A Commitment Worth Preserving: Reviving the BC Treaty Process" (Ottawa: Senate Committees Directorate, 2012), http://www.parl. gc.ca/Content/SEN/Committee/411/appa/rep/rep08jun12-e.pdf.

59. British Columbia Treaty Commission Annual Report (Vancouver: British Columbia Treaty Commission, 2011), http://bctreaty.net/files/pdf_documents/2011_Annual-Report.pdf.

60. Povinelli, Cunning, 267.

61. Claude Bachand, "An Invaluable Lever for Quebec's Aboriginal Communities," Beyond the Nass Valley: National Implications of the Supreme Court's Delgamuukw Decision, ed. Owen Lippert (Vancouver: Fraser Institute, 2000), 287-94.

62. Raymond Wilson, "To Honour Our Ancestors We Become Visible Again," Be of Good Mind: Essays on the Coast Salish, ed. Bruce Granville Miller (Vancouver: University of British Columbia Press, 2007), 131-37; Wayne Suttles, "The Persistence of Intervillage Ties among the Coast Salish," Ethnology 2, no. 4 (1963): 512-25; and Keith T. Carlson, "Innovation, Tradition, Colonialism, and Aboriginal Fishing Conflicts in the Lower Fraser Canyon," in New Histories for Old: Changing Perspectives on Canada's Native Pasts, ed. Susan Neylan and Theodore Binnema (Vancouver: University of British Columbia Press, 2007), 138-81.

63. Leonard Tsuji, Natalya Gomez, Jerry X. Mitrovica, and Roblyn Kendall, "Post-Glacial Isostatic Adjustment and Global Warming in Subarctic Canada: Implications for Islands of the James Bay Region," Arctic 62, no. 4 (2009): 458-67.

64. Thom, Paradox.

65. Brian Thom, "Coast Salish Senses of Place: Dwelling, Meaning, Power, Property and Territory in the Coast Salish World," PhD diss. (McGill University, 2005).

66. Wayne Suttles, "Affinal Ties, Subsistence, and Prestige among the Coast Salish," American Anthropologist 62, no. 2 (1960): 296-305.

67. Ingold, Territoriality and Tenure.

68. Thom, Senses of Place, 377.

69. Povinelli, Cunning, 267. 